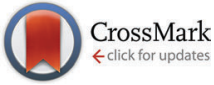

Cite this: Chem. Commun., 2016, 52,6178

Received 14th January 2016, Accepted 30th March 2016

DOI: $10.1039 / \mathrm{c} 6 \mathrm{cc00359a}$

www.rsc.org/chemcomm

\section{Photocatalytic oxidation of iron(II) complexes by dioxygen using 9-mesityl-10-methylacridinium ions $\dagger$}

Takeshi Tsudaka, ${ }^{a}$ Kei Ohkubo*ab and Shunichi Fukuzumi*abc

\begin{abstract}
Photocatalytic oxidation of iron(II) complexes by dioxygen occurred using the organic photocatalysts, 9-mesityl-10-methylacridinium ions (Acr+-Mes) and 2-phenyl-4-(1-naphthyl) quinolinium ions (QuPh $\left.{ }^{+}-\mathrm{NA}\right)$, in the presence of triflic acid in acetonitrile under visible light irradiation. The electron-transfer state of $\mathrm{Acr}^{+}-$Mes produced upon photoexcitation oxidized the iron(II) complexes, whereas it reduced dioxygen with protons to produce iron(III) complexes and $\mathrm{H}_{2} \mathrm{O}_{2}$.
\end{abstract}

Metal complexes are usually oxidized by inorganic oxidants such as cerium ammonium nitrate and lead dioxide. ${ }^{1-5}$ In such cases, stoichiometric amounts of inorganic oxidants are required to obtain oxidized metal complexes, producing inorganic wastes which cause environmental problems. The ideal oxidant, which is environmentally benign, is dioxygen $\left(\mathrm{O}_{2}\right)$, producing only hydrogen peroxide or water as the reduced product. However, the oxidation of metal complexes by $\mathrm{O}_{2}$ is often endergonic even in the presence of an acid. Thus, an appropriate photocatalyst is required for the oxidation of metal complexes by $\mathrm{O}_{2}$ in the presence of an acid. Ruthenium(II) complexes, such as $\left[\mathrm{Ru}(\mathrm{bpy})_{3}\right]^{2+}$ (bpy $=2,2^{\prime}$-bipyridine) are known to be oxidized by $\mathrm{O}_{2}$ in the presence of an acid to yield the corresponding $\mathrm{Ru}(\mathrm{III})$ complexes. ${ }^{6,7}$ On the other hand, organic photocatalysts have merited increasing attention for a variety of oxidation reactions. ${ }^{8-14}$ However, there has been no report on photocatalytic oxidation of metal complexes by $\mathrm{O}_{2}$ using organic photocatalysts.

We report herein the photocatalytic oxidation of iron(II) complexes by $\mathrm{O}_{2}$ using 9-mesityl-10-methylacridinium ions $\left(\text { Acr }^{+}-\mathrm{Mes}\right)^{15}$ and 2-phenyl-4-(1-naphthyl)quinolinium ions $\left(\mathrm{QuPh}^{+}-\mathrm{NA}\right)^{16}$ as

\footnotetext{
${ }^{a}$ Department of Material and Life Science, Graduate School of Engineering, Osaka University, ALCA and SENTAN, Japan Science and Technology Agency (JST), Suita, Osaka 565-0871, Japan. E-mail: ookubo@chem.eng.osaka-u.ac.jp; Fax: $+81-6-6879-7370$

${ }^{b}$ Department of Chemistry and Nano Science, Ewha Womans University, Seoul 120-750, Korea.E-mail: fukuzumi@chem.eng.osaka-u.ac.jp

${ }^{c}$ Faculty of Science and Technology, Meijo University, ALCA and SENTAN, Japan Science and Technology Agency (JST), Nagoya, Aichi 468-8502, Japan $\dagger$ Electronic supplementary information (ESI) available: Experimental and kinetic details. See DOI: 10.1039/c6cc00359a
}

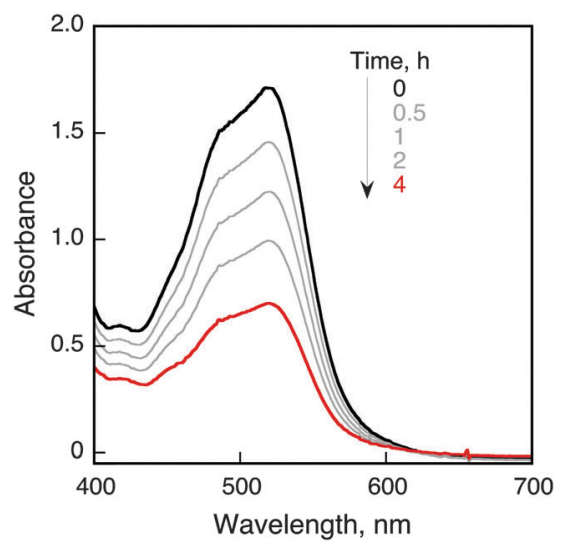

Fig. 1 Visible absorption change in photocatalytic oxidation of $\left[\mathrm{Fe}^{\prime \prime}(\mathrm{bpy})_{3}\right]^{2+}$ $\left(\mathrm{PF}_{6}{ }^{-}\right)_{2}(2.0 \mathrm{mM})$ by $\mathrm{O}_{2}$ in $\mathrm{O}_{2}$-saturated $\mathrm{MeCN}$ in the presence of [Acr ${ }^{+}$-Mes]$\left(\mathrm{ClO}_{4}{ }^{-}\right)(0.20 \mathrm{mM})$ and $\mathrm{HOTf}(0.10 \mathrm{M})$ at $298 \mathrm{~K}$ under visible light irradiation using a xenon lamp with a cut filter $(\lambda<390 \mathrm{~nm})$.

organic photocatalysts in the presence of triflic acid (HOTf) in acetonitrile (MeCN) under visible light irradiation [eqn (1)]. Visible light irradiation of $\mathrm{O}_{2}$-saturated acetonitrile is shown in Fig. 1, where the absorption band at $520 \mathrm{~nm}$ due to $\left[\mathrm{Fe}^{\mathrm{II}}(\mathrm{bpy})_{3}\right]^{2+}$ decreased, accompanied by the increase in absorption at $650 \mathrm{~nm}$ due to $\left[\mathrm{Fe}^{\mathrm{III}}(\mathrm{bpy})_{3}\right]^{3+} \cdot\left[\mathrm{Fe}^{\mathrm{II}}(\mathrm{bpy})_{3}\right]^{2+}$ was not oxidized without Acr $^{+}-$Mes under irradiation (Fig. S1 and S2 in the ESI $\dagger$ ). The reduced product of $\mathrm{O}_{2}$ was $\mathrm{H}_{2} \mathrm{O}_{2}$, which was detected by spectral titration with the use of the oxo[5,10,15,20-tetra(4-pyridyl)porphyrinato]titanium(Iv) complex (see the Experimental section in the ESI $\dagger$ ). ${ }^{17}$

$$
2 \mathrm{Fe}^{\mathrm{Il}}+\mathrm{O}_{2}+2 \mathrm{H}^{+} \frac{h v}{\text { Photocatalyst }}
$$


The photocatalytic oxidation of other iron(II) complexes by $\mathrm{O}_{2}$ was examined in the presence of HOTf in $\mathrm{O}_{2}$-saturated MeCN (Fig. S3-S6 in the ESI $\dagger$ ). The quantum yields of formation of iron(III) complexes were determined using a ferrioxalate actinometer (see Fig. S7-S9 and the Experimental section in the ESI $\dagger) .{ }^{18}$ The quantum yields $(\Phi)$ of photocatalytic oxidation of iron(II) complexes by $\mathrm{O}_{2}$ in the presence of HOTf in MeCN are listed in Table 1 together with the concentrations of iron(II) complexes, HOTf and $\mathrm{O}_{2}$, the one-electron oxidation potentials of iron(II) complexes $\left(E_{\mathrm{ox}}\right)^{19}$ and the free energy change of the oxidation $\left(\Delta G_{\mathrm{ox}}\right)$. The $\Delta G_{\mathrm{ox}}$ values were evaluated from the $E_{\mathrm{ox}}$ values and the $E_{\text {red }}$ value of $\mathrm{O}_{2}$ in the presence of an acid in MeCN (0.75 V vs. SCE) [eqn (2)]. ${ }^{20}$

$$
\Delta G_{\text {ox }}=-2 e\left(E_{\text {red }}-E_{\text {ox }}\right)
$$

Judging from the $\Delta G_{\text {ox }}$ values, the photocatalytic oxidation of $\left[\mathrm{Fe}^{\mathrm{II}}(\text { Clphen })_{3}\right]^{2+},\left[\mathrm{Fe}^{\mathrm{II}}(\mathrm{bpy})_{3}\right]^{2+}$ and $\left[\mathrm{Fe}^{\mathrm{II}}\left(\mathrm{Me}_{2} \mathrm{bpy}\right)_{3}\right]^{2+}$ is endergonic, whereas that of $\mathrm{Fe}^{\mathrm{II}}\left(\mathrm{BrC}_{5} \mathrm{H}_{4}\right)_{2}$ and $\mathrm{Fe}^{\mathrm{II}}\left(\mathrm{BrC}_{5} \mathrm{H}_{4}\right)\left(\mathrm{C}_{5} \mathrm{H}_{5}\right)$ is exergonic. The $\Phi$ values increased with the decreasing the $E_{\mathrm{Ox}}$ values of iron(II) complexes as the free energy change of the reaction in eqn (1) decreased to be thermodynamically more favourable. Dependence of $\Phi$ on concentrations of $\left[\mathrm{Fe}^{\mathrm{II}}(\mathrm{bpy})_{3}\right]^{2+}\left(\mathrm{PF}_{6}{ }^{-}\right)_{2}$, HOTf and $\mathrm{O}_{2}$ is shown in Fig. 2 (parts a, b and c, respectively). The $\Phi$ value became constant with the increasing concentrations of $\left[\mathrm{Fe}^{\mathrm{II}}(\mathrm{bpy})_{3}\right]^{2+}\left(\mathrm{PF}_{6}{ }^{-}\right)_{2}$, HOTf and $\mathrm{O}_{2}$, respectively. The photocatalytic oxidation of iron(II) complexes is enhanced by using $\mathrm{QuPh}^{+}$-NA instead of $\mathrm{Acr}^{+}-\mathrm{Mes}$ as shown in Table 1. (Fig. S10-S14 in the ESI $\dagger$ ).

Nanosecond laser flash photolysis measurements were performed in order to clarify the catalytic mechanism for photocatalytic oxidation of iron(II) complexes by $\mathrm{O}_{2}$ using Acr $^{+}$-Mes in the presence of HOTf in MeCN. Transient absorption spectra were taken after the nanosecond laser excitation at $355 \mathrm{~nm}$ of a deaerated MeCN solution of $\mathrm{Acr}^{+}$-Mes in the absence and presence of $\left[\mathrm{Fe}^{\mathrm{II}}(\mathrm{bpy})_{3}\right]^{2+}\left(\mathrm{PF}_{6}{ }^{-}\right)_{2}$ as shown in Fig. 3. The transient absorption band at $490 \mathrm{~nm}$ is due to the electron-transfer state of $\mathrm{Acr}^{+}$-Mes. In the presence of $\left[\mathrm{Fe}^{\mathrm{II}}(\mathrm{bpy})_{3}\right]^{2+}$ the absorption at $490 \mathrm{~nm}$ decayed more rapidly and the decay rate increased with the increasing concentration of $\left[\mathrm{Fe}^{\mathrm{II}}(\mathrm{bpy})_{3}\right]^{2+}$. The decay rate obeyed pseudo-first-order kinetics and the pseudo-first order rate constant increased linearly with the increasing concentration of $\left[\mathrm{Fe}^{\mathrm{II}}(\mathrm{bpy})_{3}\right]^{2+}\left(\mathrm{PF}_{6}{ }^{-}\right)_{2}$. From the slope the rate constant $\left(k_{\mathrm{ox}}\right)$ of electron transfer from $\left[\mathrm{Fe}^{\mathrm{II}}(\mathrm{bpy})_{3}\right]^{2+}$ to the electron-transfer state of $\mathrm{Acr}^{+}$-Mes was determined to be
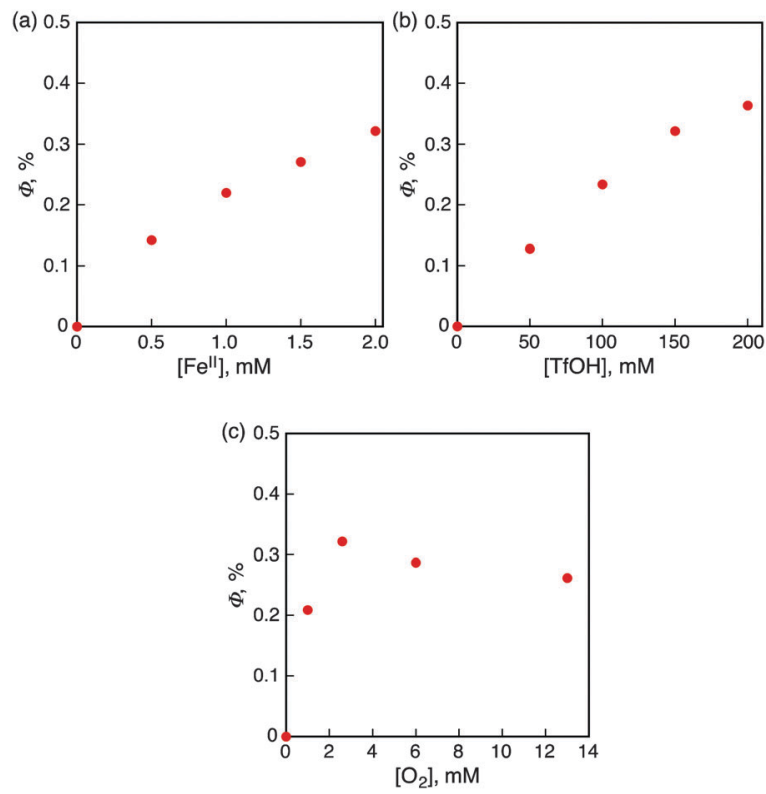

Fig. 2 Dependence of $\Phi$ on concentrations of (a) $\left[\mathrm{Fe}^{\prime \prime}(\mathrm{bpy})_{3}\right]^{2+}$, (b) HOTf and (c) $\mathrm{O}_{2}$. Standard conditions: $\left[\left[\mathrm{Acr}^{+}-\mathrm{Mes}\right]\left(\mathrm{ClO}_{4}^{-}\right)\right]=1.0 \mathrm{mM}$; $\left[\left[\mathrm{Fe}^{\mathrm{e}}(\mathrm{bpy})_{3}\right]^{2+}\left(\mathrm{PF}_{6}{ }^{-}\right)_{2}\right]=$ $2.0 \mathrm{mM} ;[\mathrm{HOTf}]=0.15 \mathrm{M} ;\left[\mathrm{O}_{2}\right]=2.6 \mathrm{mM}$; dehydrated $\mathrm{MeCN}(0.40 \mathrm{~mL})$; cell path length $0.1 \mathrm{~cm}$; excitation wavelength: $420 \mathrm{~nm}$.

$3.7 \times 10^{8} \mathrm{M}^{-1} \mathrm{~s}^{-1}$ as shown in the inset of Fig. 3. Similarly the $k_{\mathrm{ox}}$ values of other iron(II) complexes were determined (see Fig. S15-S23 in the ESI $\dagger$ ) as listed in Table 2 together with the $E_{\mathrm{ox}}$ values. The $k_{\mathrm{ox}}$ value increases with the decreasing $E_{\mathrm{ox}}$ values. In the presence of $\mathrm{O}_{2}$, electron transfer from the electrontransfer state of Acr $^{+}$-Mes to $\mathrm{O}_{2}$ is known to occur with a rate constant of $6.8 \times 10^{8} \mathrm{M}^{-1} \mathrm{~s}^{-1} .^{21}$ The rate constant of electron transfer from the electron-transfer state of $\mathrm{QuPh}^{+}-\mathrm{NA}$ to $\mathrm{O}_{2}$ was determined to be $6.3 \times 10^{8} \mathrm{M}^{-1} \mathrm{~s}^{-1}$ (see Fig. S24 in the ESI $\dagger$ ). Thus, the photocatalytic oxidation of iron(II) complexes $\left(\mathrm{Fe}^{\mathrm{II}}\right)$ by $\mathrm{O}_{2}$ in the presence of HOTf proceeds as shown in Scheme 1. Photoexcitation of $\mathrm{Acr}^{+}$-Mes results in the formation of the electron-transfer state of $\mathrm{Acr}^{+}$-Mes, which oxidizes iron(II) complexes to iron(III) complexes and reduces $\mathrm{O}_{2}$ with protons to produce $\mathrm{HO}_{2}{ }^{\bullet}$, which disproportionates to yield $\mathrm{H}_{2} \mathrm{O}_{2}$.

In conclusion, iron(II) complexes are oxidized to iron(III) complexes by $\mathrm{O}_{2}$ using Acr $^{+}$-Mes as an organic photocatalyst in the presence of HOTf in MeCN under visible light irradiation via electron-transfer oxidation of iron(II) complexes and reduction of

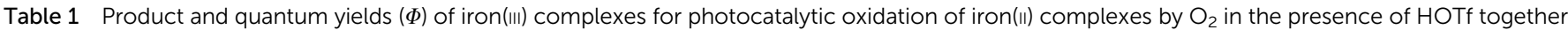
with the one-electron oxidation potentials of iron(॥) complexes $\left(E_{\text {ox }}\right)$ and the free energy change of the oxidation $\left(\Delta G_{\text {ox }}\right)$

\begin{tabular}{|c|c|c|c|c|c|c|c|c|c|}
\hline Entry & $\mathrm{Fe}^{\mathrm{II}}$ complex & $E_{\mathrm{Ox}}$ vs. $\mathrm{SCE}^{a}, \mathrm{~V}$ & $\Delta G_{\mathrm{ox}}, \mathrm{eV}$ & Acr $^{+}-$Mes yield ${ }^{d}, \%$ & TON & $\Phi^{f}, \%$ & $\mathrm{QuPh}^{+}-\mathrm{NA}$ yield ${ }^{e}, \%$ & TON & $\Phi^{f}, \%$ \\
\hline$\overline{1^{b}}$ & {$\left[\mathrm{Fe}^{\mathrm{II}}(\text { Clphen })_{3}\right]^{2+}$} & 1.20 & 0.90 & 5 & 0.25 & 0.11 & 30 & 1.5 & 0.34 \\
\hline $2^{b}$ & {$\left[\mathrm{Fe}^{\mathrm{II}}(\mathrm{bpy})_{3}\right]^{2+}$} & 1.06 & 0.62 & 42 & 4.2 & 0.32 & 32 & 3.5 & 0.73 \\
\hline $3^{b}$ & {$\left[\mathrm{Fe}^{\mathrm{II}}\left(\mathrm{Me}_{2} \mathrm{bpy}\right)_{3}\right]^{2+}$} & 0.88 & 0.26 & 22 & 2.1 & 1.6 & 30 & 3.0 & 5.2 \\
\hline $4^{c}$ & $\mathrm{Fe}^{\mathrm{II}}\left(\mathrm{BrC}_{5} \mathrm{H}_{4}\right)_{2}$ & 0.72 & -0.06 & 81 & 4.1 & 7.2 & 87 & 4.2 & 13 \\
\hline $5^{c}$ & $\mathrm{Fe}^{\mathrm{II}}\left(\mathrm{BrC}_{5} \mathrm{H}_{4}\right)\left(\mathrm{C}_{5} \mathrm{H}_{5}\right)$ & 0.53 & -0.44 & 81 & 4.1 & 19 & 60 & 3.0 & 26 \\
\hline
\end{tabular}

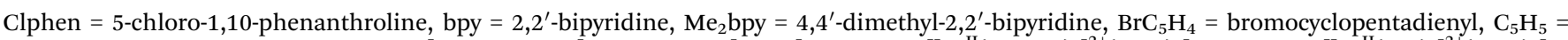

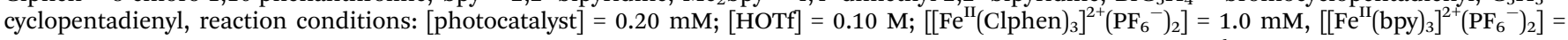

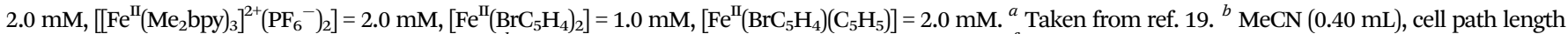
$0.1 \mathrm{~cm} .{ }^{c} \mathrm{MeCN}(3.0 \mathrm{~mL})$, cell path length $1 \mathrm{~cm} .{ }^{d}$ Photoirradiation $(\lambda>390 \mathrm{~nm}) .{ }^{e}(\lambda>300 \mathrm{~nm}) .{ }^{f}$ See the Experimental section in the ESI. 


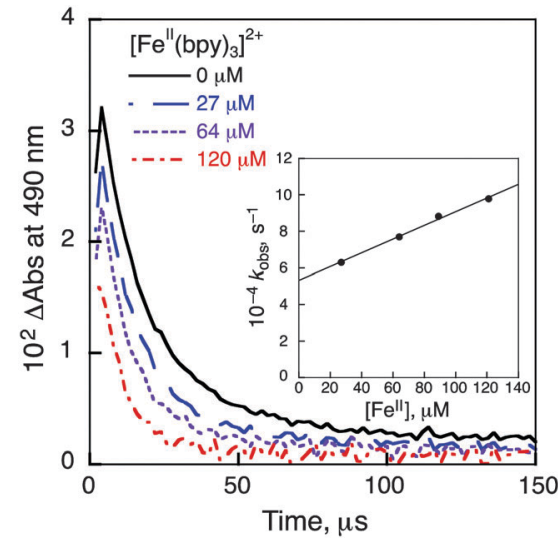

Fig. 3 Transient absorption decay at $490 \mathrm{~nm}$ due to the electron-transfer state of $\left[\mathrm{Acr}{ }^{+}-\mathrm{Mes}\right]\left(\mathrm{ClO}_{4}{ }^{-}\right)$with various concentrations of $\left[\mathrm{Fe}{ }^{\prime \prime}(\mathrm{bpy})_{3}\right]^{2+}\left(\mathrm{PF}_{6}{ }^{-}\right)_{2}$. Inset: Decay rate constant versus concentrations of $\left[\mathrm{Fe}^{\prime \prime}(\mathrm{bpy})_{3}\right]^{2+}\left(\mathrm{PF}_{6}{ }^{-}\right)_{2}$.

Table 2 Rate constants of electron transfer from iron(II) complexes to the electron-transfer state of the organic photocatalyst and the one-electron oxidation potentials of iron(II) complexes $\left(E_{\text {ox }}\right)$

\begin{tabular}{lllll}
\hline Entry & $\mathrm{Fe}^{\mathrm{II}}$ complex & $\begin{array}{l}E_{\text {ox }} v s . \\
\text { SCE, V }\end{array}$ & $\begin{array}{l}\mathrm{Acr}^{+}-\mathrm{Mes} k_{\mathrm{et}}, \\
\mathrm{M}^{-1} \mathrm{~s}^{-1}\end{array}$ & $\begin{array}{l}\mathrm{QuPh}^{+}-\mathrm{NA} k_{\mathrm{et}} \\
\mathrm{M}^{-1} \mathrm{~s}^{-1}\end{array}$ \\
\hline 1 & {$\left[\mathrm{Fe}^{\mathrm{II}}(\mathrm{Clphen})_{3}\right]^{2+}$} & 1.20 & $1.4 \times 10^{8}$ & $4.9 \times 10^{8}$ \\
2 & {$\left[\mathrm{Fe}^{\mathrm{II}}(\mathrm{bpy})_{3}\right]^{2+}$} & 1.06 & $3.7 \times 10^{8}$ & $4.5 \times 10^{8}$ \\
3 & {$\left[\mathrm{Fe}^{\mathrm{II}}\left(\mathrm{Me}_{2} \mathrm{bpy}\right)_{3}\right]^{2+}$} & 0.88 & $4.5 \times 10^{8}$ & $5.8 \times 10^{8}$ \\
4 & $\mathrm{Fe}^{\mathrm{II}}\left(\mathrm{BrC}_{5} \mathrm{H}_{4}\right)_{2}$ & 0.72 & $7.6 \times 10^{9}$ & $7.2 \times 10^{9}$ \\
5 & $\mathrm{Fe}^{\mathrm{II}}\left(\mathrm{BrC}_{5} \mathrm{H}_{4}\right)\left(\mathrm{C}_{5} \mathrm{H}_{5}\right)$ & 0.53 & $8.5 \times 10^{9}$ & $7.9 \times 10^{9}$
\end{tabular}

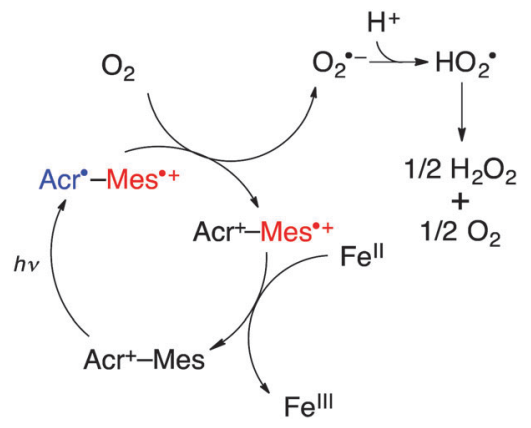

Scheme 1 Photocatalytic cycle for oxidation of iron(॥) complexes to iron(III) by $\mathrm{O}_{2}$ with $\mathrm{Acr}^{+}$-Mes.

$\mathrm{O}_{2}$ by the electron-transfer state of Acr-Mes produced upon photoexcitation of $\mathrm{Acr}^{+}$-Mes, respectively. The present study provides an environmentally benign approach for oxidation of metal complexes by $\mathrm{O}_{2}$ to obtain the oxidised metal complexes and hydrogen peroxide $\left(\mathrm{H}_{2} \mathrm{O}_{2}\right)$. Because there are many synthetically useful oxidation reactions using $\mathrm{H}_{2} \mathrm{O}_{2},{ }^{22}$ this study has paved a new way for photocatalytic oxidation of substrates by $\mathrm{O}_{2}$ with organic photocatalysts and iron(II) complexes.

This work was supported by Grants-in-Aid (no. 26620154 and 26288037 to K. O.) from the Ministry of Education, Culture, Sports, Science and Technology (MEXT); ALCA and SENTAN projects from JST, Japan (to S. F.).

\section{Notes and references}

1 (a) L. Duan, A. Fischer, Y. Xu and L. Sun, J. Am. Chem. Soc., 2009, 131, 10397; (b) T. Ishizuka, S. Ohzu and T. Kojima, Synlett, 2014, 1667.

2 (a) M. Murakami, D. Hong, T. Suenobu and S. Fukuzumi, J. Am. Chem. Soc., 2011, 133, 11605; (b) T. Kojima, K. Nakayama, K. Ikemura, T. Ogura and S. Fukuzumi, J. Am. Chem. Soc., 2011, 133, 11692.

3 D. Hong, S. Mandal, Y. Yamada, Y.-M. Lee, W. Nam, A. Llobet and S. Fukuzumi, Inorg. Chem., 2013, 52, 9522-9531.

4 (a) G. P. McDermott, P. Jones, N. W. Barnett, D. N. Donaldson and P. S. Francis, Anal. Chem., 2011, 83, 5453; (b) M. P. Patel, S. A. Varnum, D. Gandla, M. J. Zdilla and C. J. Martoff, Anal. Methods, 2014, 6, 5818.

5 (a) S. Fukuzumi, C. L. Wong and J. K. Kochi, J. Am. Chem. Soc., 1980, 102, 2928; (b) S. Fukuzumi, K. Miyamoto, T. Suenobu, E. Van Caemelbecke and K. M. Kadish, J. Am. Chem. Soc., 1998, 120, 2880-2889; (c) S. Fukuzumi, H. Miyao and T. Suenobu, J. Phys. Chem. A, 2005, 109, 3285-3294.

6 A. Das, V. Joshi, D. Kotkar, V. S. Pathak, V. Swayambunathan, P. V. Kamat and P. K. Ghosh, J. Phys. Chem. A, 2001, 105, 6945-6954.

7 S. Kato, J. Jung, T. Suenobu and S. Fukuzumi, Energy Environ. Sci., 2013, 6, 3756-3764.

8 (a) M. Fagnoni, D. Dondi, D. Ravelli and A. Albini, Chem. Rev., 2007, 107, 2725; (b) D. Ravelli, M. Fagnoni and A. Albini, Chem. Soc. Rev., 2013, 42, 97.

9 (a) D. A. Nicewicz and T. M. Nguyen, ACS Catal., 2014, 4, 355-360; (b) D. A. Nicewicz and D. S. Hamilton, Synlett, 2014, 1191-1196.

10 D. Ravelli and M. Fagnoni, ChemCatChem, 2012, 4, 169.

11 (a) K. Ohkubo and S. Fukuzumi, Bull. Chem. Soc. Jpn., 2009, 82, 303; (b) S. Fukuzumi and K. Ohkubo, Chem. Sci., 2013, 4, 561.

12 D. Ravelli, D. Dondi, M. Fagnoni and A. Albini, Chem. Soc. Rev., 2009, 38, 1999.

13 (a) M. L. Marin, L. Santos-Juanes, A. Arques, A. M. Amat and M. A. Miranda, Chem. Rev., 2012, 112, 1710; $(b)$ M. L. Marin, A. Miguel, L. Santos-Juanes, A. Arques, A. M. Amat and M. A. Miranda, Photochem. Photobiol. Sci., 2007, 6, 848.

14 Y. Pan, S. Wang, C. W. Kee, E. Dubuisson, Y. Yang, K. P. Loh and C.-H. Tan, Green Chem., 2011, 13, 3341.

15 (a) S. Fukuzumi, H. Kotani, K. Ohkubo, S. Ogo, N. V. Tkachenko and H. Lemmetyinen, J. Am. Chem. Soc., 2004, 126, 1600; (b) S. Fukuzumi, H. Kotani and K. Ohkubo, Phys. Chem. Chem. Phys., 2008, 10, 5159.

16 (a) H. Kotani, K. Ohkubo and S. Fukuzumi, Faraday Discuss., 2012, 155, 89; (b) Y. Yamada, T. Miyahigashi, H. Kotani, K. Ohkubo and S. Fukuzumi, J. Am. Chem. Soc., 2011, 133, 16136.

17 C. Matsubara, N. Kawamoto and K. Takamura, Analyst, 1992, 117, 1781.

18 C. G. Hatchard and C. A. Parker, Proc. R. Soc. London, Ser. A, 1956, 235, 518-536.

19 (a) J. Park, Y.-M. Lee, W. Nam and S. Fukuzumi, J. Am. Chem. Soc., 2013, 135, 5052; (b) H. Yoon, Y.-M. Lee, X. Wu, K.-B. Cho, R. Sarangi, W. Nam and S. Fukuzumi, J. Am. Chem. Soc., 2013, 135, 9186.

20 R. Cofé and D. T. Sawyer, Inorg. Chem., 1986, 25, 2089.

21 H. Kotani, K. Ohkubo and S. Fukuzumi, J. Am. Chem. Soc., 2004, 126, 15999.

22 (a) A. Fingerhut, O. V. Serdyuk and S. B. Tsogoeva, Green Chem., 2015, 17, 2042; (b) Y. Zhu, Q. Wang, R. G. Cornwall and Y. Shi, Chem. Rev., 2014, 114, 8199; (c) S. Fukuzumi and K. Ohkubo, Asian J. Org. Chem., 2015, 4, 836. 